\title{
There is No Texting at James Baldwin's Table
}

\author{
Lindsey R. Swindall Stevens Institute of Technology
}

\begin{abstract}
Clearly there is a unique hunger for Baldwin's wisdom in this historical moment, as illustrated by Raoul Peck's film, reprints of several Baldwin books, exhibits, and other events. This essay describes the genesis of two five-part public discussions on the works of James Baldwin that were co-facilitated by African-American Studies scholar Dr. Lindsey R. Swindall and actor Grant Cooper at two schools in New York City in the 2016-17 academic year. These discussion series led to numerous Baldwin discussion events being scheduled for the winter and spring of 2018. The surprising popularity of these programs prompted Swindall to wonder: Why do people want to discuss Baldwin now? The first of two parts, this essay speculates that many people in the digital age long for a conversational space like the one Baldwin created at the "welcome table" in his last home in France. The second essay-which is forthcoming-will confirm whether discussion events held in 2018 harmonize with the welcome table thesis.
\end{abstract}

Keywords: James Baldwin, African-American history, the welcome table, public discussion, public scholarship

There is a noteworthy hunger for James Baldwin's wisdom at this historical juncture. This has recently been illustrated by Raoul Peck's critically praised film I Am Not Your Negro, reprints of several Baldwin books, and exhibits relating to the writer. ${ }^{1}$ This phenomenon came to my attention in 2016 when I responded to a call for grant applications by Humanities New York to facilitate public reading and discussion of Baldwin's work. The original project involved leading a five-part series at a middle school in Harlem with co-facilitator Grant Cooper, an artist from NYC, in the fall of 2016. That series generated interest from a high school in Manhattan where we led another five-part series in the spring of 2017. The conversation at this series was so thoughtful that the school invited us to return in the spring

James Baldwin Review, Volume 4, 2018, ( The Authors. Published by Manchester University Press and The University of Manchester Library 
of 2018. In the meantime, we offered a discussion program on Baldwin in response to the launching of the Public Scholars Project by the New Jersey Council for the Humanities. Even though our most recent iteration began just three months ago, seven non-profit organizations around the state have scheduled a Baldwin discussion session with us in 2018. I am also slated to give a guest lecture in a newly created Baldwin literature course at Stevens Institute of Technology in 2018. That's right, an engineering university has just commenced a seminar on Baldwin.

So much engagement around Baldwin in such a short span of time has been exciting, but it has also prompted me to consider the import of this present fascination. Why Baldwin, I wondered, and why now? This essay will examine the possible forces driving the current emphasis on Baldwin that is happening, significantly, not in traditional academic circles but in more ostensibly public spaces like museums, movie theaters, libraries, and community centers. This is Baldwin for the masses in the twenty-first century, and, in my experience, it seems to be happening organically. There is no singular mandate except that people are interested in and want to talk about Baldwin. Now. This essay posits that the fear-driven culture of present-day media, coupled with the superficiality of much of today's discourse, has people longing for the kind of heartfelt interpersonal conversation that was fostered at Baldwin's own dining table at his final home in France. Recreating that "welcome table" by discussing Baldwin's writing is helping to fulfill a need for human connection and meaningful exchange within today's culture.

At the time of his death in 1987, one of the projects James Baldwin was in the process of creating was a play called The Welcome Table. Baldwin biographer David Leeming explained it was meant to be a "slice-of-life" play wherein "What happens on the surface seems to go nowhere, but we sense below the surface a struggle with open wounds."2 The play was rooted in and partially recreated the social setting of Baldwin's own home. It was the table in his St. Paul-de-Vence dining room "around which life in the household was centered." ${ }^{3}$ His self-exile from the racism of the United States had not diminished Baldwin's magnetism, or the desire of visitors to bare their souls at his table. In his quiet refuge in southern France, Baldwin struggled to heal his depression from having lost Medgar, Martin, and Malcolm; meanwhile artists, travelers, activists, and seekers from all corners of the globe took the path to the small Provençal village where Baldwin was holding court. New and old friends, current and past lovers, present-day luminaries and writers whose celebrity was budding all shared in Baldwin's hospitality, including Harry Belafonte, Maya Angelou, Angela Davis, Nikki Giovanni, and Quincy Troupe. ${ }^{4}$ The table which Baldwin headed became a "must stop" outing for many who were visiting the country. ${ }^{5}$ Sharing drinks, cigarettes, and conversation long into the night, Baldwin's welcome table was a comfortable space. By all accounts, he was "great company" whether entertaining in his home or drinking with the local villagers in conservative St. Paul. ${ }^{6}$

The welcome table enabled admirers and others in exile to sit with Baldwin and absorb his wisdom. Having a "band of followers" develop around him was nothing new for the writer. It had happened, for example, when he was teaching back in 
the United States in Bowling Green, Ohio and in Amherst, Massachusetts where he sometimes even brought students into his home for classes. ${ }^{7}$ The welcome table in France was a vital place for both bearing witness and laying bare the heart. Leeming notes the "confessional milieu" of the table in Baldwin's home where he had spent much time. ${ }^{8}$ There was a spiritual aspect to the communion that took place at the welcome table. When the saints communed together in the church of Baldwin's youth, they ate the bread of life and it sustained them until they reached their reward in the next world. ${ }^{9}$ At Baldwin's welcome table, he and others could testify to the truths of this world. While there might not be an immediate resolution, there is a cleansing that occurs in bearing witness that can elevate the spirit. The confessional process is essential to achieving the genuine human connectedness which we all need in order to survive. Baldwin wrote in 1964, "The moment we cease to hold each other, the moment we break faith with one another, the sea engulfs us and the light goes out." ${ }^{10}$ At Baldwin's welcome table faith between people could grow safely, and individuals could learn to trust each other through the discovery of their shared history, common frailties, and mutual pain. The nourishing of human bonds is a holy venture because it is the path through which a society achieves wholeness. I am coming to see the significance of Baldwin in public discussion more clearly as these projects blossom. However, I had no such lofty assumptions when first embarking on the idea of facilitating a Baldwin discussion group.

In the spring of 2016, I noticed a call for grant applications to recruit facilitators from Humanities New York for their Adult Reading and Discussion groups. I had recently done a pilot of an interactive dramatic program on Paul Robeson with Grant Cooper, who portrayed the great actor-activist, at Harlem West Middle School. Our program was based on one of my books, Paul Robeson: A Life of Activism and Art. ${ }^{11}$ Few of our students had heard of Robeson, but many were visibly touched by his story. We were thrilled by the curiosity and inquisitiveness of the young students, and had been pondering whether there could be a way to engage further with the Success Academy (SA) charter network. When I saw that the work of James Baldwin was one of the themes for the Adult Reading and Discussion groups, I felt that conversing about Baldwin in Harlem could be a powerful opportunity to interact with those students and to bring a broad spectrum of people together. Cooper and I pitched the idea of writing a grant proposal for a discussion series at Harlem West to SA CEO Eva Moskowitz. Moskowitz had responded quickly when we proposed our Paul Robeson program, and, once again, she rapidly gave us a green light to proceed with the application for the Baldwin series. Cooper and I felt that Harlem West's administrators, staff, parents, students, and community members could provide a rich audience of participants across ethnic, class, and gender lines which would be ideal for an exploration of Baldwin's writing. Humanities New York accepted our proposal to facilitate a Baldwin series hosted by SA, and Cooper and I began preparing for the first gathering.

Facilitating the discussions as a pair was a deliberate pedagogical strategy. We felt that an interracial team with a man and a woman was important since we knew that our audience would be comprised of people from many diverse backgrounds. 
It was vital, in our minds, that everyone feel comfortable and able to share if they desired. Baldwin is, at times, utterly and excruciatingly transparent about his own life in his work, and so we aimed to create an open, safe space for all participants that honored transparency and truth. In addition, we aimed to close each conversation by highlighting an aspect of Baldwin's ethos of love. Cooper and I each concluded independently that Baldwin's ability to reveal piercing truths about humanity was made possible by what scholar Phillip Luke Sinitiere has elegantly labeled Baldwin's "radical ethic of love." 2 In "A Letter to My Nephew" Baldwin explains that change can occur when "we, with love, shall force our brothers to see themselves as they are ...."13 This is the kind of love found at a welcome table. Love that sometimes has to be "a battle" in order to be a catalyst for truly bearing witness. ${ }^{14}$ This was the kind of love, we hoped, that could build a bond between participants so they could open up within the context of a public discussion.

Cooper and I trusted that building on the foundational notion of Baldwin's love for humanity would pave the way to discuss openly some of the raw truths expressed in Baldwin's writing. His assertion about the creation of "the nigger," for example, is relevant to any community with an underclass, and places the onus of hierarchy not on those whose humanity is degraded, but on those who ignore the humanity of others. He writes, "But if I was a 'nigger' in your eyes, there was something ... you needed."15 Baldwin continues, "it is a terrible, an inexorable, law that one cannot deny the humanity of another without diminishing one's own ...." 16 These are not easy truths with which to grapple, but within the space of a welcome table they can be addressed honestly. It was our transparency, coupled with our unique perspectives on Baldwin, that helped to facilitate some of the most heartfelt conversations on race and the nature of life that I have ever witnessed. Sharing about ourselves was essential to creating an approachable conversation for all contributors. Cooper and I opened each series by revealing some personal history and the ways in which we each had first encountered Baldwin.

My co-facilitator, Grant Cooper, like many of our African-American discussion participants, has much in common with Baldwin. Like Baldwin, Cooper was the oldest in a family with many children whose early lives were shaped by forces including urban poverty and Pentecostal religion. The years Cooper spent growing up in Camden, New Jersey related easily with Baldwin's, and many of our participants', experiences in New York City. Both Cooper and Baldwin left home as teenagers. While Baldwin traveled in his young adult years in order to write, Cooper's international voyages took place through the U.S. Navy. He encountered the hostility of racism at its most vitriolic when he was stationed in Charleston, South Carolina on a ship, the U.S.S. Semmes, that was named for a Confederate general. The name calling and racial discrimination that Cooper experienced on board that ship was eye opening, since they were all volunteers serving their country. There were numerous sailors on board, men who openly displayed racist tattoos and Confederate flags, who did not attempt to hide their animosity for his skin color. Yet when the crew was at sea, the jobs undertaken by all on board were vital for the ship to return safely. They had to depend on each other. However, learning 
to work together for the overall security of the vessel only temporarily mitigated the racism on board. While at sea, the men functioned as a single unit, but when the ship came into port back home everyone, black and white, went their separate ways.

Cooper discovered Baldwin's work outside of a classroom context, and the writer strengthened his sense of African-American identity. His perspective on Baldwin is, thus, very personal from the shared elements of their subjective histories, their common anger, and a mutual thirst for telling the truth about the human experience. Coincidentally, my personal history was also rooted in Charleston, which often intrigued discussion participants. Cooper and I met in New York City over seventeen years ago, but we were both molded, in part, by our past experiences in South Carolina.

I moved to the southern town in middle school, and attended junior high and high schools there. These schools were named for rice plantations that were still standing just down the highway, and part of me always wondered about the connections between rice, slavery, the city, and its inhabitants. I never got any satisfactory answers, so I kept pursuing the historical narrative through a bachelor's degree at the University of South Carolina, travel to Europe and Africa, and ultimately a doctorate in African-American Studies. One summer, between my undergraduate and graduate schooling, I encountered Baldwin's interview with Kenneth Clark from 1963 in a slim volume from the public library. ${ }^{17} \mathrm{I}$ had never read anything like it. When Baldwin asserted, "If I'm not a nigger and you, the white people invented him, then you've got to find out why. And the future of the country depends on that," it felt like a call to action to me. ${ }^{18}$ The idea that white people were the ones who needed to take the responsibility of getting to the root of racism was new to me. The urgency of his tone sincerely moved me. I read everything on Baldwin at the library that year, and undertook a grueling self-examination, sometimes throwing a book across the room when his words pierced my spirit. Baldwin was facilitating my journey in coming to terms with what it meant to be an American who grew up in the South.

Everyone must deal with the collective histories they inherit, and it was just this sort of truth-based journey that Cooper and I hoped our discussion series would instigate. Before launching the first discussion group, Cooper and I spent a sunny autumn afternoon sitting by Baldwin's grave at Ferncliff Cemetery in Hartsdale, New York. We had intended simply to pay our respects and leave, but once we arrived the weather and natural beauty of the place beckoned us to stay longer. We read some of Baldwin's poetry aloud, ate a simple picnic lunch, and drank a toast in his honor.

We rooted our approach to each discussion in sharing the historical context of the piece being analyzed-driven by my scholarly approach to Baldwin-as well as personal reaction-propelled by Cooper's artistic and anecdotal take on the writer. The dual character of this pedagogy turned out to be quite effective. I opened each session with a brief contextual overview, and we would highlight a few passages with dramatic readings by Cooper. One of us would then share a perspective to get 
the conversation started. It was vital that we listened to everyone's point of view on Baldwin. We did not want people to feel they had to have any previous knowledge of Baldwin to participate, because this was not an academic course. There were no grades to be given or agendas to fulfill, but only insights to share. A participant's lived experience, not a degree or certificate, meant his or her voice was relevant.

This method of facilitating discussion led to several of what I refer to as "welcome table moments," which were instances of bonding or mutual understanding that were fostered by Baldwin's words. Many participants traveled to the evening discussion sessions from other parts of New York City by train after a full day's work. Students and teachers had been in school since early in the morning. We ensured that there were always refreshments available about a half hour before the discussions commenced so that people could relax for a moment, get a bite to eat, and look over the reading that would be discussed that night. Having a literal welcome table laid for people prior to the discussions set a comfortable, relaxed tone that was conducive to sharing. Cell phones were banned from the literal and metaphorical welcome table to enable participants truly to pay attention to one another, a rare gift in the present age.

In February 2017, Cooper and I took a group of students from our Baldwin discussion group to see the film I Am Not Your Negro at Lincoln Center in NYC. While we were all chatting on the train, one of the young students, Azira, took a seat and started to read. I noticed that she was riveted by a rather worn hardcover copy of Just Above My Head. I inquired about the origin of the book, and she explained that when she started attending our James Baldwin discussions, her dad had lent her this prized first edition which had the author's signature emblazoned on the cover. While sharing this story with us she was undeterred by the noise and bustle of the subway stops and was clearly proud when the other students gathered tightly around her, focusing on the treasure which she possessed. The Baldwin series had connected her with her father in a new and meaningful way. He was a Baldwin admirer as was his mother before him. The act of loaning the dogeared volume signified something of a rite of passage. Here, I thought, Baldwin was uniting this father-daughter duo in a closer bond. It was a "welcome table" moment.

After the second session of the spring 2017 discussion series, the principal of the high school where we met came up to me and noted that these discussions had been "the most authentic engagement" between parents, staff, and students that had ever occurred at the school. I paused for a moment processing his comment, then it quickly made sense: of course, this had been an authentic engagement. All we did was prepare a welcome table and let Baldwin's words initiate the communion. The participants took the mission seriously, and Baldwin was present at the table, inspiring participants to bear witness to the life experiences that resonated with his words.

Welcome table moments such as these demonstrate that there is a longing within many people to participate in a meaningful communion with others, and this is, I believe, drawing people to Baldwin's work in public discussion at this moment. Recreating the kind of global community discourse that was fostered at Baldwin's 
own welcome table can help to fill today's void of substantial dialogue and meaningful human connection. In a beautiful way, gathering in groups to read Baldwin's words can help reestablish the vital components of the welcome table that he hosted in France. The trust of the confessional milieu that grows from a sense of human bonding is rooted in careful, deliberate listening. This occurs with Baldwin's work on several levels.

Baldwin's writing urges us first to listen to ourselves as we read. Take, for example, the speech "In Search of a Majority." In wrestling with the notion of identity, he asserts, "The question is what we really want out of life, for ourselves, what we think is real." ${ }^{19}$ The reflective reader pauses here, listens to his or her internal dialogue, and considers how to respond to this inquiry. Baldwin also enables us to use his writing as a point of entry to listen to each other. "The necessity" of achieving an identity, he writes, "is a historical and a present personal fact and this is the connection between you and me." ${ }^{20}$ In the context of a discussion group, Baldwin has initiated here a marvelous vehicle for fostering genuine connection. This works best when the participants really listen to each other. Because Baldwin's words on the page bear witness to the truth, he is offering his readership the opportunity to bear witness to each other. Baldwin, still seated at the welcome table, invites us to converse, to pay attention to ourselves and to each other through his work. The onus of fostering these relationships is now on his readers; however, Baldwin has lovingly laid the table in preparation for us to come take our seats.

At the heart of bearing witness is attention: paying careful attention so that one can share the truths of the world. Possibly no one paid attention to the world more closely and commented on it more shrewdly than James Baldwin. Paying closer attention to each other across the political aisle, across the borders of nations, across the fences in our communities is the path to navigating the global political crises in which we currently find ourselves. Everyone needs Baldwin's welcome table in this era, perhaps more than ever. The onslaught of fear-based and anxiety-inducing news is overwhelming to the human mind and heart in the digital era. The culture of fear-terrorist events, war atrocities, acts of racism, political chaos-explodes into people's daily realities globally as well as virtually through electronic devices that are checked addictively. While anxiety seems to grow exponentially in this age, conversely, communication is condensed. We speak face-to-face less frequently, use fewer words, pay less sustained attention to each other. Emoticons do not cultivate meaningful discourse. Twittering does not foster richer human connectedness. Texting does not nurture authentic trust and love. "Love is a growing up," Baldwin reminds us. ${ }^{21}$ We cannot bring smartphones to a welcome table and develop the kind of genuine love for humankind that is the only road to the salvation of humanity. This is the Baldwin we need in the digital era: the prophet who urges us to pay attention, who enables us to listen to ourselves and each other, who bears witness so that we might also share the whole truth, who reassures us that "The world is before you and you need not take it or leave it as it was when you came in."22

As I write, it is a frigid Martin Luther King, Jr. Day in the northeastern United States. I am reminded of King's conception of the beloved community. ${ }^{23}$ It was a 
cornerstone of his dream, and one that has not yet been realized by humanity. Taking a seat at a welcome table might be a legitimate avenue to creating a new kind of society grounded in love. I feel hopeful but wonder: How many people want to sit at Baldwin's table? Can conversations about Baldwin sustain more "welcome table moments"? Can these interactions really increase connectedness in the digital age? These will be the kinds of questions I will be asking at our Baldwin discussions in 2018. A library director in a small town in New Jersey recently told me she has been looking for something on Baldwin to bring to her community. I can't wait to go there to find out why, and to invite the people in that neighborhood to join us at a welcome table.

\section{Notes}

1 For example, reprints include the unique photo collection from 1964, Richard Avedon and James Baldwin, Nothing Personal (Cologne, Taschen, 2017) and the book for young people, James Baldwin, Little Man, Little Man: A Story of Childhood (Durham, N.C., Duke University Press, August 2018). There was an exhibit focusing on Nothing Personal at the Pace Gallery in New York City from November 2017 through January 2018. In France, Baldwin artifacts as well as his final home are being preserved by the group La Maison Baldwin, which opened a welcome center in St. Paul-de-Vence in 2017.

2 David Leeming, James Baldwin: A Biography (New York, Alfred A. Knopf, 1994), p. 373.

3 Ibid., p. 374.

4 Jules B. Farber, James Baldwin: Escape from America, Exile in Provence (Gretna, LA, Pelican Publishing, 2016), chapter 2.

5 Todd Steven Burroughs, "James Baldwin Scholars Confront France," Africology: The Journal of Pan African Studies, 9 (2016), p. 401.

6 Ibid.

7 Leeming, James Baldwin, pp. 340, 365.

8 Ibid., p. 374.

9 See, for example, James Baldwin, Go Tell It on the Mountain (New York, Dell Publishing, 1985), pp. 14-15.

10 James Baldwin, "Nothing Personal," Contributions in Black Studies, 6 (2008), p. 60.

11 Lindsey R. Swindall, Paul Robeson: A Life of Activism and Art (Lanham, MD, Rowman and Littlefield, 2015).

12 Phillip Luke Sinitiere, "James Baldwin: Biographical Sketches on a Freedom Writer," James Baldwin Review, 2 (2016), p. 149.

13 James Baldwin, The Fire Next Time (New York, Dell Publishing, 1985), p. 21.

14 James Baldwin, "In Search of a Majority: An Address," in Collected Essays, ed. Toni Morrison (New York, Library of America, 1998), p. 220.

15 James Baldwin, "A Talk to Teachers," in Morrison (ed.), Collected Essays, p. 682.

16 James Baldwin, "Fifth Avenue, Uptown: A Letter from Harlem," in Morrison (ed.), Collected Essays, p. 179.

17 Kenneth B. Clark, interviewer, The Negro Protest (Boston, Beacon Press, 1963).

18 Fred R. Standley and Louise H. Pratt (eds.), Conversations with James Baldwin (Jackson, MS, University Press of Mississippi, 1989), p. 45.

19 Baldwin, "In Search of a Majority," p. 218.

20 Ibid., p. 221. 
21 Ibid., p. 220.

22 Ibid., p. 221.

23 See, for example, Martin Luther King, Jr., "Nonviolence and Racial Justice," in A Testament of Hope: The Essential Writings and Speeches of Martin Luther King, Jr., ed. James M. Washington (New York, Harper One, 2003), pp. 5-10.

\section{Works Cited}

Avedon, Richard, and James Baldwin, Nothing Personal (Cologne, Taschen, 2017).

Baldwin, James, "Fifth Avenue, Uptown: A Letter from Harlem," in Collected Essays, ed. Toni Morrison (New York, Library of America, 1998), pp. 170-9. The Fire Next Time (New York, Dell Publishing, 1988). Go Tell It on the Mountain (New York, Dell Publishing, 1985). "In Search of a Majority: An Address," in Collected Essays, ed. Toni Morrison (New

York, Library of America, 1998), pp. 215-21. Jimmy's Blues and Other Poems (Boston, Beacon Press, 2014). Little Man, Little Man: A Story of Childhood (Durham, N.C., Duke University Press, August 2018). "Nothing Personal," Contributions in Black Studies, 6 (2008), pp. 49-60. The Price of the Ticket: Collected Non-Fiction 1948-1985 (New York, St. Martin's Press, 1985).

"A Talk to Teachers," in Collected Essays, ed. Toni Morrison (New York, Library of America, 1998), pp. 678-86.

Blint, Rich, and Nazar Buyum. "'I'm Trying to be as Honest as I Can:' An Interview with James Baldwin," James Baldwin Review, 1 (2015), pp. 112-29.

Burroughs, Todd Steven, "James Baldwin Scholars Confront France," Africology: The Journal of Pan African Studies, 9 (2016), pp. 400-3.

Clark, Kenneth B., interviewer, The Negro Protest (Boston, Beacon Press, 1963).

Farber, Jules B., James Baldwin: Escape from America, Exile in Provence (Gretna, LA, Pelican Publishing, 2016).

"How I Got Over: Filmmaker Raoul Peck." Interview with Rebecca Carroll, The Greene Space, New York City, 2 February 2017.

King, Martin Luther, Jr., "Nonviolence and Racial Justice," in A Testament of Hope: The Essential Writings and Speeches of Martin Luther King, Jr., ed. James M. Washington (New York, Harper One, 2003), pp. 5-10.

Lebron, Christopher J., The Making of Black Lives Matter: A Brief History of an Idea (New York, Oxford University Press, 2017).

Leeming, David, James Baldwin: A Biography (New York, Alfred A. Knopf, 1994). "James Baldwin: Voyages in Search of Love," James Baldwin Review, 1 (2015), pp. 130-9.

Peck, Raoul (dir.), I Am Not Your Negro (New York, Magnolia Pictures, 2017).

Sinitiere, Phillip Luke, “James Baldwin: Biographical Sketches on a Freedom Writer," James Baldwin Review, 2 (2016), pp. 140-52.

Standley, Fred R., and Louise H. Pratt (eds.), Conversations with James Baldwin (Jackson, MS, University Press of Mississippi, 1989).

Swindall, Lindsey R., Paul Robeson: A Life of Activism and Art (Lanham, MD, Rowman and Littlefield, 2015).

Thorsen, Karen (dir.), James Baldwin: The Price of the Ticket (San Francisco: California Newsreel, 1990). 


\section{Contributor's Biography}

Lindsey R. Swindall holds a doctorate in African-American Studies and teaches U.S. history as well as the Freshman Colloquium at Stevens Institute of Technology in Hoboken, New Jersey. She has written and edited several books, the most recent of which is The Path to the Greater, Freer, Truer World: Southern Civil Rights and Anticolonialism, 1937-1955. Working with actor Grant Cooper, Swindall enjoys dramatizing themes from her biography Paul Robeson: A Life of Activism and Art for middle school, high school, and college students. She also collaborates with Cooper on several programs that are part of the New Jersey Council for the Humanities' Public Scholars Project. 